\title{
CUSTOMER PURCHASE BEHAVIOUR AND SHOPPING IN B2C E-COMMERCE
}

\author{
Petra JÍLKOVÁī*, Petra KRÁLOVÁ(iD* \\ Masaryk Institute of Advanced Studies, Czech Technical University in Prague, \\ Kolejni 2637/2a, Czech Republic \\ "E-mails:petra.jilkova@cvut.cz,petra.kralova@cvut.cz
}

\begin{abstract}
Purpose - digitalization of business processes, cultural backgrounds and consequences on behavioral differences make a direct impact on customer purchase behavior across different countries. The main aim of this paper is to analyze the effect of the economic situation in the selected countries regarding the e-commerce business.

Research methodology - first, the paper presents a theoretical model for customer purchase behavior and the development of the theory in the B2C e-commerce context. Second, it is analyzed the main aspects of shopping behavior in selected countries.

Findings - a difference between traditional and e-commerce customer purchase behavior model was found. Next, the research shows the main characteristics of shopping in $\mathrm{B} 2 \mathrm{C}$ and provides a better understanding of the impact of digitalization.

Research limitations - research will focus on the shopping in B2C e-commerce market in the Czech Republic, Lithuania and in the European Union. The data is based on the Czech Statistical Office, which covers a period from 2010 to 2018 and the respondents of the survey purchased online in the 12 months prior to 2018.

Practical implications - the paper confirmed the fact that the $\mathrm{B} 2 \mathrm{C}$ e-commerce market in the Czech Republic is developed and has potential to grow nationally and internationally. It is necessary to further investigate the relationship between customer purchase behavior, e-commerce, and other economic indicators, possibly including other factors.
\end{abstract}

Originality/Value - the paper investigates online shopping for the period between 2010-2018. Finally, the authors discuss the theoretical and practical implications of these results.

Keywords: b2c, customer journey, customer purchase behavior, e-commerce, e-logistics, shopping, STDC concept.

JEL Classification: M31, O33, L86.

Conference topic: Digitalization of Business Processes: Trends, Challenges, Solutions.

\section{Introduction}

New technologies are speeding up the connection between the virtual and physical worlds, enabling the emergence of new business models. Digitalization has rapidly changed B2B and B2C traditional business models, as digital technologies have influenced the marketing product in significant but unforeseeable ways. Furthermore, expectations are increasing due to their advantages. Digitalization and the impact of digital skills and technologies into nearly all factors of work is rapidly changing not only industries and markets but also the traditional business attitude on how to offer products and services to e-customers. E-commerce business and e-sales can be done via websites, applications; or in an automated way via messages, enterprises may offer one or both options to their clients. These specific methods enable the traditional sales process to take place in a faster and more efficient method. Globally, e-commerce is growing, and this has been supported by the use of smart-phones. People aged 25-34 comprise a majority of active e-shoppers ( $81 \%$ of internet users) than any other age group. Employees and the self-employed ( $75 \%$ of internet users) as well as students (70\%) shop online far more than retired/inactive or unemployed people (both 54\%) (Eurostat, 2019).

The e-commerce business model provides many benefits to both sellers and buyers. Alam, Ali, and Jani (2011) investigate factors affecting the intention to adopt e-commerce in the SMEs. Over the last several years, a significant increase in the automation of different work tasks, advances in technologies and adoption of new e-processes, has resulted in the digitalization and robotization of some popular consumer technologies. To keep up with these changes, companies are required to accept the ongoing integration of information technologies to support the digital transformation of these firms. Work was previously done by employees, such as obtaining data from multiple sources, and 
transferring them to other systems, e.g. Customer Relationship Management Systems (CRMS) or Enterprise Resource Planning (ERP), has been automatized and done by an application where a robot is usually used. According to Eurostat, $71 \%$ of EU enterprises selling electronically used only websites or apps, ranging from $53 \%$ in the Czech Republic to 91\% in Greece (Eurostat, 2019).

E-commerce within the Czech Republic is growing. The biggest increase is among young people (aged 25-34), mothers on maternity leave and pensioners. By comparing gender women purchase more than men (2018). The most popular type of goods and services purchased online in the Czech Republic were clothes, sporting goods, and accommodation, which is similar to the EU (CSO). Consumers appreciate their ability to compare goods easily, lower prices, and the convenience of home shopping. The growing trend is obvious in a number of e-shops, it counts for around 40000 e-shops within the Czech Republic. APEK refers to an approximate turnover of 135 billion CZK during 2018.

This research provides a deeper understanding of how the internet and digitalization of business process, cultural backgrounds and consequences on behavioral differences make a direct impact on customer purchase behaviors across different countries. The main aim of this paper is to analyze the effect of the economic situation in the selected countries regarding the e-commerce business. Firstly, the article demonstrates the main principles of customer purchase behavior and presents a theoretical model and development of the theory in the $\mathrm{B} 2 \mathrm{C}$ e-commerce context.

Secondly, this research analyses the main aspects of shopping behavior in selected countries, the research shows the main characteristics of shopping in $\mathrm{B} 2 \mathrm{C}$ and provides a better understanding of the impact of digitalization. In addition, a literature review and analysis of secondary data are based on publishing on or before January 2019. Finally, implications for further academic research and marketing practice are discussed. Digitalization of business processes, cultural backgrounds, and the consequences of behavioral differences make a direct impact on customer purchase behaviors across different countries.

\section{Literature review}

Online marketing has transformed marketing communication and how the organization communicates with its customers. Marketers have been moving away from mass marketing, and instead, are dividing the market into segments. In so doing, marketing managers can acquire a better understanding of the needs and wants of customers. In traditional marketing, customers are segmented into groups according to segmentation parameters. Target marketing involves the identification of the most profitable market segments and integrated marketing communication is usually created for these customers, such as a promotional program, to obtain the desired response rate.

Marketing mix originates from the 4Ps concept (price, place, product, promotion) of McCarthy $(1960,1964)$ to Borden's (1965) original marketing mix, which had a set of 12 elements (product planning, pricing, branding, channels of distribution, personal selling, advertising, promotions, packaging, display, servicing, physical handling, and factfinding and analysis). While there were a lot of modifications to the 4Ps framework (Mindak \& Fine, 1981; Kotler, 1986; Waterschoot \& Bulte, 1992) the most widespread concept has come with services. Booms and Bitner (1981) added three additional components (process, physical evidence, and participants) to the 4Ps framework. Bhatt and Emdad (2001) transforms the classical 4Ps by adding a new dimension and showing how the virtual value chain can have an impact on these traditional four Ps of marketing. The virtual value chain can provide a number of options to customers to customize products and services. Constantinides (2002) defined the 4S model (Scope: Strategic issues, Site: Operational issues, Synergy: Organisational issues, System: Technological issues). The 5Ds (digital devices, digital platforms, digital media, digital data, and digital technology) of digital marketing was introduced by Chaffey and Chadwick (2019).

For the last $15 y e a r$ value creation for the customer has been put forward as a critical variable in marketing. Brands are focused on storytelling. Social media-based brand communities are playing an important role in enhancing the overall trust relationship, value offering, sociality, knowledge and information sharing between customers and firms (Potgieter \& Naidoo, 2017). Content marketing is a strategic marketing approach focused on creating and distributing valuable, relevant, and consistent content to attract and retain a clearly-defined audience - and, ultimately, to drive profitable customer action (CMI, 2017). This is in line with Pulizzi (2012), Järvinen and Taiminen (2016).

Forouzandeh, Soltanpanah, and Sheikhahmadi (2014) mentioned that digital marketing is mostly used on social media channels, which is the reason why current marketing campaigns have a bigger audience compared to campaigns in the past. The phrase delivering value to customers implies that value is inserted in the products and services delivered to customers for their use. Several marketing strategists (Huber, Herrmann, \& Morgan, 2001; Reichheld, Robert, \& Hopton, 2000) underline that the creation of customer value is a key element for ensuring the success of B2C companies. Marketing strategies changed from a one-way to a two-way communication process. According to Dhingra and Dhingra (2013), Maroofi, Darabi, and Torabi (2012) the use of e-Customer Relationship Management can play the main role in online customer satisfaction formation, relationship quality, trust and it can support adequate service quality. Thanks to digital solutions, the advantages of serverless, integrated, and complex end-to-end data analytics services that go beyond limits can be realized. This open market is also more cost-effective. According to Kumar and Malik (2013), e-CRM can be defined as a strategic technology-centric relationship marketing business model, combining traditional CRM with e-business market place applications. The application of the e-Customer Relationship 
Management system can affect the effectiveness of the marketing business model and can manage online customer relationships while building loyalty. Online B2B and B2C have been implementing various strategies to attract and retain e-customers. The present study focuses specifically on the impact of selected aspects of the online shopping experience. Mosteller, Donthu, and Eroglu (2014); Machleit and Davis (2003) show a significant effect of site atmospherics on shopper attitudes, satisfaction, and various approach/avoidance behaviors as a result of the emotions experienced during the shopping process. Mosteller, Donthu, and Eroglu (2014) examined how consumers' perceived fluency of verbal online information affects their perceived cognitive effort and positive effect within a choice context. Consumer purchase behavior analysis is a key aspect of the success of e-business.

Although the AIDA model was developed a century ago, the basic principle of the model is still relevant, in spite of a variety of modifications. Solomon (2010) defined that the key to the successful implementation of the AIDA model is to understand the mental state of the buyer. This is a very complex process that requires skill and experience. AIDA is a model of communication that is designed to capture the process that firms go through to reach prospective buyers to sell their products and services. There are four main steps such as Attention, Interest, Desire, Action (Belch, 2008) and Satisfaction (Kotler \& Armstrong, 2003, 2011). Montazeribarforoushi, Keshavarzsaleh, and Ramsøy, (2017) connected the response hierarchy models with neuroscience. Based on there, they concluded that the AIDA model is not applicable and substantially problematic (see Figure 1).

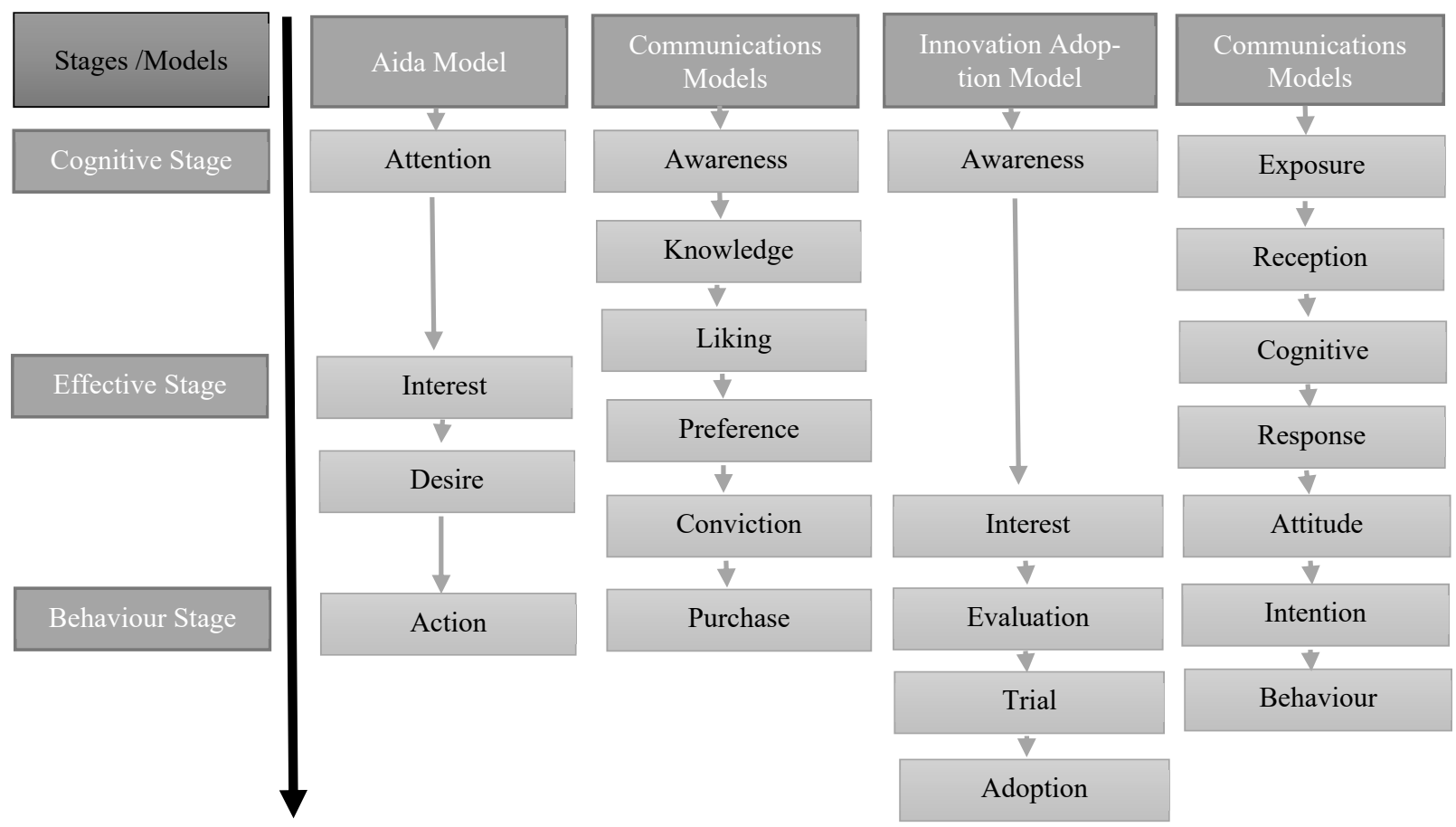

Figure 1. Response hierarchy models (source: Montazeribarforoushi, Keshavarzsaleh, \& Ramsoy, 2017)

These trends bring a new STDC concept created in 2015 by Google company. We could say that the STDC framework could have four main steps (See-Think-Do-Care stage). The See stage includes what Kaushik (2015) said is a brand's largest qualified addressable audience, the Think stage is the segment of consumers thinking about a particular thing, the Do stage includes consumers ready to buy, and the Care is the ongoing communication thereafter that inspires repeat purchases. Implementation of this concept to the marketing thinking and to the marketing communication concept is not easy, it might be applied the See - Think - Do - Care Framework when we discussing and implementing the optimization of a website to drive organic search, conversions, and revenue. Thinking about this model is the future of marketing communication and implementing the concept of content marketing into e-commerce customer purchase behavior model. This is in line with Kim and Choi (2019) that mentioned that the relationship between a social media platform and users' value co-creation to offer is based on four core drivers of social media success include experience, satisfaction, expression, and sharing ability. Each of these drivers, in turn, contains conditions for understanding users' value-creation process and the creation of drivers for successful social media strategies. Mercadé-Melé, Molinillo, Fernández-Morales, and Porcu (2018) develops a model to socially responsible activity on perceived corporate social responsibility (CSR) and its influence on consumer loyalty. The paper presents a theoretical model for customer purchase behavior and the development of the theory in the B2C e-commerce context. A difference between traditional and e-commerce customer purchase behavior model was found. Next, the paper is analyzing the main aspects of shopping behavior in selected countries, the research shows the main characteristics of shopping in $\mathrm{B} 2 \mathrm{C}$ and provides a better understanding of the impact of digitalization. 


\section{Research methodology}

The data is based on the Czech Statistical Office, which covers a period from 2010 to 2018 (respondents of the survey purchased online in the 12 months prior to 2018). It will focus on the shopping in B2C e-commerce market in the Czech Republic, Lithuania and in the European Union in comparison with the context of the economic situation. The methodologies used in this paper are the analysis, synthesis, the comparison in time. The conclusion sums up the findings and discusses them. Data analyses providing a deeper insight into a modern customer purchase behavior developing and implementing a creative customer-oriented strategy.

\subsection{Economic situation}

The data presented by the Czech Statistical Office shows the development of the purchases during the period between 2010 till 2018. (Respondents of the survey purchased online in the last 12-month period prior to 2018.) The data allows you to compare the situation in the Czech Republic and within the EU. This article is focused on the situation in the Czech Republic, specifically the purchases related to the gender, age, education and type of goods and services purchased.

Table 1. Internet users/buyers in the Czech Republic in the last 12-month period, the percentage share of whole individuals in the socio-demographic group. Individuals according to gender (source: Czech Statistical Office)

\begin{tabular}{|c|c|c|c|c|c|c|c|c|c|}
\hline Period & 2010 & 2011 & 2012 & 2013 & 2014 & 2015 & 2016 & 2017 & 2018 \\
\hline Total 16+ & $\mathbf{2 5 . 4}$ & $\mathbf{2 8 . 0}$ & $\mathbf{3 0 . 6}$ & $\mathbf{3 4 . 4}$ & $\mathbf{3 9 . 3}$ & $\mathbf{4 1 . 9}$ & $\mathbf{4 3 . 6}$ & $\mathbf{5 1 . 6}$ & $\mathbf{5 3 . 9}$ \\
\hline Gender & & & & & & & & & \\
\hline Men 16+ & 28.0 & 29.0 & 31.5 & 35.6 & 40.5 & 42.6 & 42.3 & 53.0 & 53.6 \\
\hline Women 16+ & 23.0 & 26.9 & 29.8 & 33.4 & 38.1 & 41.2 & 44.9 & 50.3 & 54,2 \\
\hline
\end{tabular}

Table 1 presents the proportion of individuals who purchased online within the last 12 months between 2010 and 2018. The proportion of individuals (aged 16+) are constantly growing during the focused period. The indicators (the data) illustrate the difference between purchases for men and women. Men aged 16+ bought online proportionally more than women, except for 2016 and 2018.

Table 2. Internet users/buyers in the Czech Republic in the last 12 months period, the percentage share of whole individuals in the socio-demographic group. Individuals according to age (source: Czech Statistical Office)

\begin{tabular}{|c|c|c|c|c|c|c|c|c|c|}
\hline Age & 2010 & 2011 & 2012 & 2013 & 2014 & 2015 & 2016 & 2017 & 2018 \\
\hline $16-24$ & 38.8 & 40.5 & 46.3 & 53.9 & 62.2 & 60.6 & 58.7 & 69.8 & 71.0 \\
\hline $25-34$ & 44.5 & 48.0 & 54.3 & 58.3 & 63.2 & 66.9 & 72.0 & 79.1 & 81.3 \\
\hline $35-44$ & 34.7 & 39.3 & 43.1 & 46.9 & 52.6 & 59.2 & 59.4 & 70.9 & 71.4 \\
\hline $45-54$ & 22.1 & 25.3 & 27.9 & 32.4 & 40.1 & 41.2 & 46.6 & 56.2 & 63.8 \\
\hline $55-64$ & 10.5 & 13.1 & 15.7 & 19.8 & 21.7 & 25.7 & 28.3 & 38.6 & 41.2 \\
\hline $65+$ & 3.0 & 3.7 & 3.9 & 4.5 & 7.6 & 8.0 & 9.7 & 12.7 & 13.5 \\
\hline
\end{tabular}

The increase in online shopping is evident in every age group (see Table 2 and Table 3 ). The highest share was for individuals aged between 25 and 34 . The $65+$ age group is constantly increasing as well. 13.5\% of this demographic group bought online 12 months prior to 2018 .

Table 3. Internet users/buyers in the Czech Republic in last 12-month period, percentage share of whole individuals in the sociodemographic group. Individuals according to economic activity (source: Czech Statistical Office)

\begin{tabular}{|c|c|c|c|c|c|c|c|c|c|}
\hline Economic activity $(16+)$ & 2010 & 2011 & 2012 & 2013 & 2014 & 2015 & 2016 & 2017 & 2018 \\
\hline Employed & 32.7 & 35.9 & 39.8 & 45.0 & 50.3 & 53.8 & 56.0 & 66.5 & 68.4 \\
\hline Unemployed & 39.7 & 25.7 & 25.7 & 27.3 & 33.8 & 33.8 & 31.5 & 36.7 & 38.5 \\
\hline Mother on maternity leave & $\mathrm{n} / \mathrm{a}$ & $\mathrm{n} / \mathrm{a}$ & $\mathrm{n} / \mathrm{a}$ & 55.1 & 64.6 & 65.5 & 72.4 & 77.6 & 82.7 \\
\hline Students & 40.7 & 40.9 & 46.9 & 54.5 & 62.5 & 61.4 & 58.3 & 68.5 & 69.5 \\
\hline Old-age pensioner & 3.7 & 4.4 & 4.2 & 6.4 & 8.4 & 9.9 & 11.4 & 14.5 & 15.5 \\
\hline Disabled pensioner & $\mathrm{n} / \mathrm{a}$ & $\mathrm{n} / \mathrm{a}$ & $\mathrm{n} / \mathrm{a}$ & 15.7 & 19.4 & 17.3 & 22.8 & 28.4 & 32.4 \\
\hline
\end{tabular}


The highest proportion are university educated individuals. (76\% in the 12 months prior to 2018), the lowest proportion are people with basic education (16.5\% in the 12 months prior to 2018). The percentage share according to economic activity presents the high share of mothers on maternity leave, students and employed people. $82.7 \%$ of mothers on maternity leave purchased online in the 12 months prior to $2018.69 .5 \%$ of students and $68.4 \%$ of employed individuals bought online, in 12 months prior to 2018. The trend within all these groups is increasing. The mothers on maternity leave demographic have enormous potential for the future especially for purchasing of goods for family, kids, and household.

The comparison between the EU and the Czech Republic illustrates the chart below. The individuals in the Czech Republic, in comparison with the EU, who purchased online in the last 12 months (Figure 2). They are aged 16 to 74 . The chart shows that both indicators are increasing and the gap between these two is getting lower.

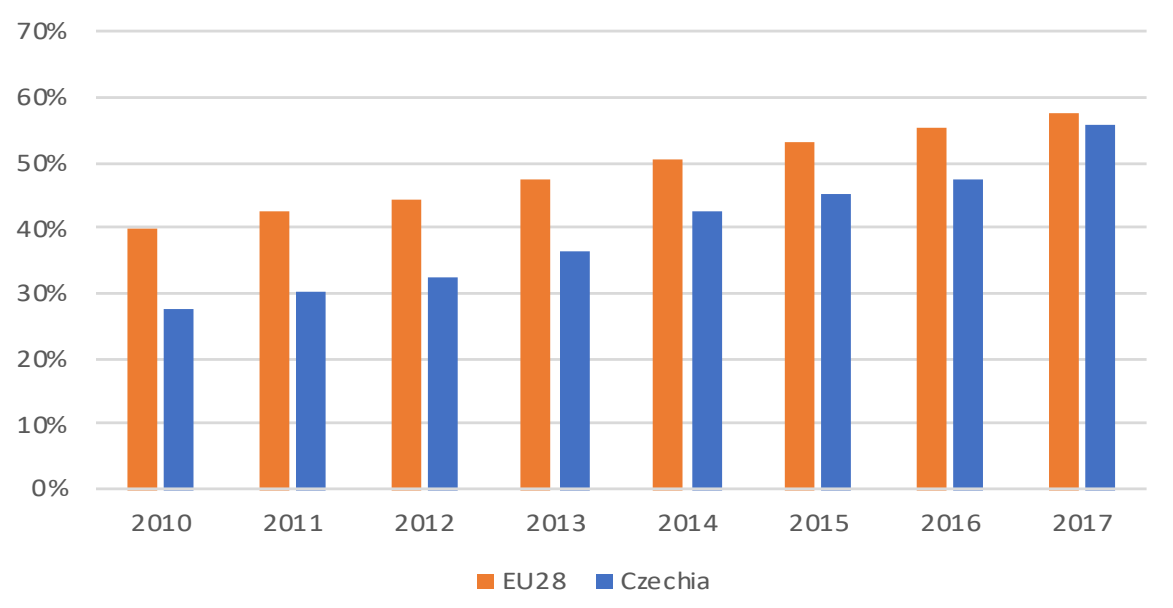

Figure 2. Internet users/buyers in the Czech Republic and the EU in the last 12-month period, the percentage share of whole individuals in the socio-demographic group, aged 16-74 (source: Czech Statistical Office)

The chart presents a comparison between the EU average, the Czech Republic and Lithuania. The chart expresses an increasing trend in these analyzed countries during the period 2010-2017 (Figure 3).

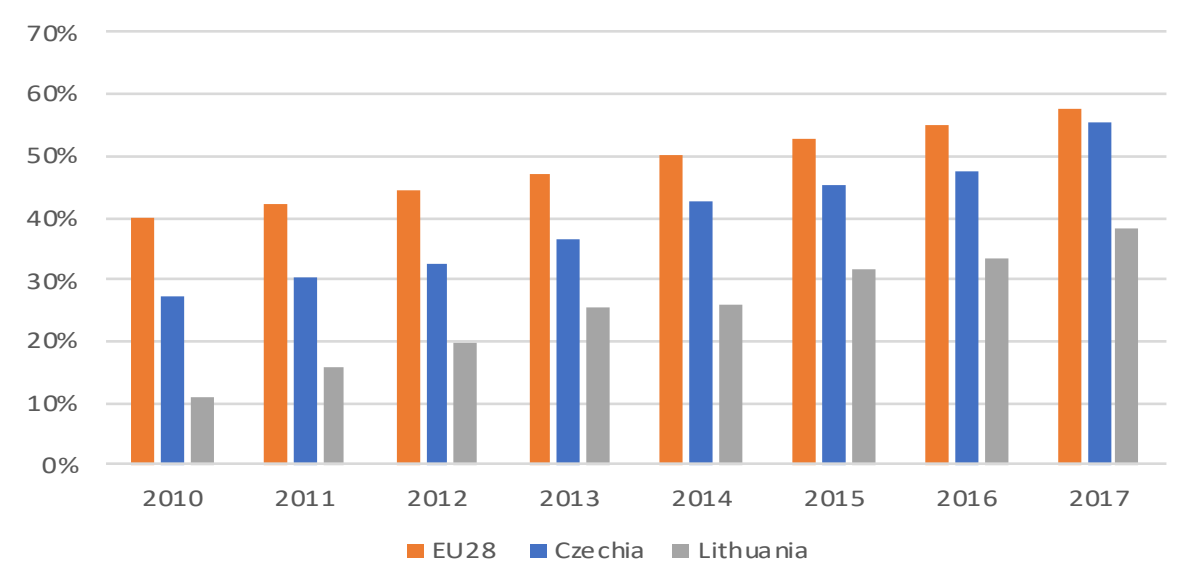

Figure 3. Internet users/buyers in the Czech Republic and the EU in the last 12-month period, the percentage share of whole individuals in the socio-demographic group, aged 16-74, EU, Czechia, Lithuania comparison (source: Czech Statistical Office)

Following figures (Figure 4) express GDP (recalculated for one person and expressed in PPS, average EU 28 equals 100) and the proportion of individuals who bought online in the last 12 months. In general, the well-developed countries (high PPS) are in correlation with the high share (\%) of online purchasing. Exceptions are Lichtenstein and Ireland where the online purchase penetration is not so high. 


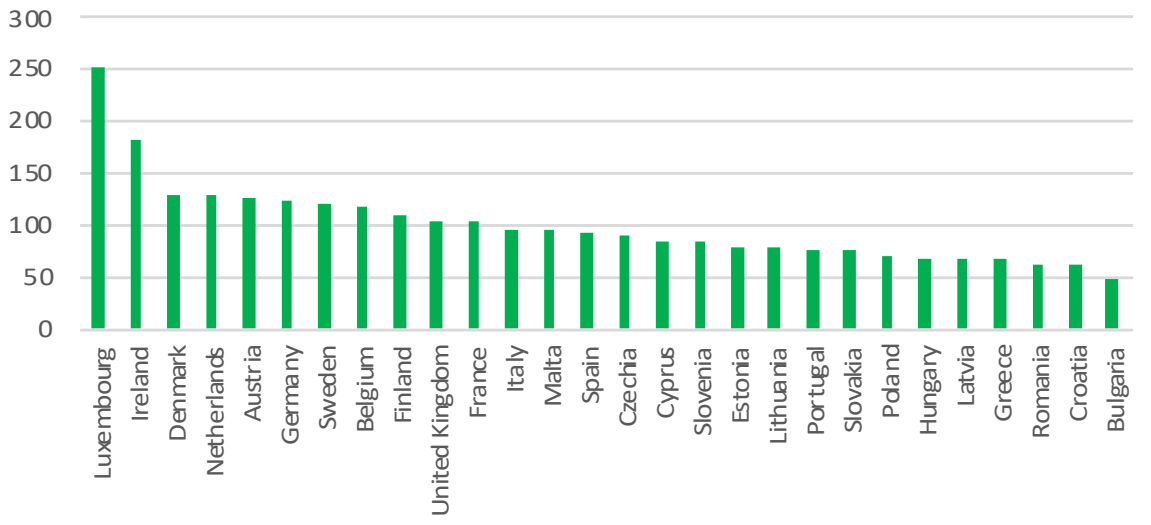

Figure 4. PPS in EU (source: Czech Statistical Office)

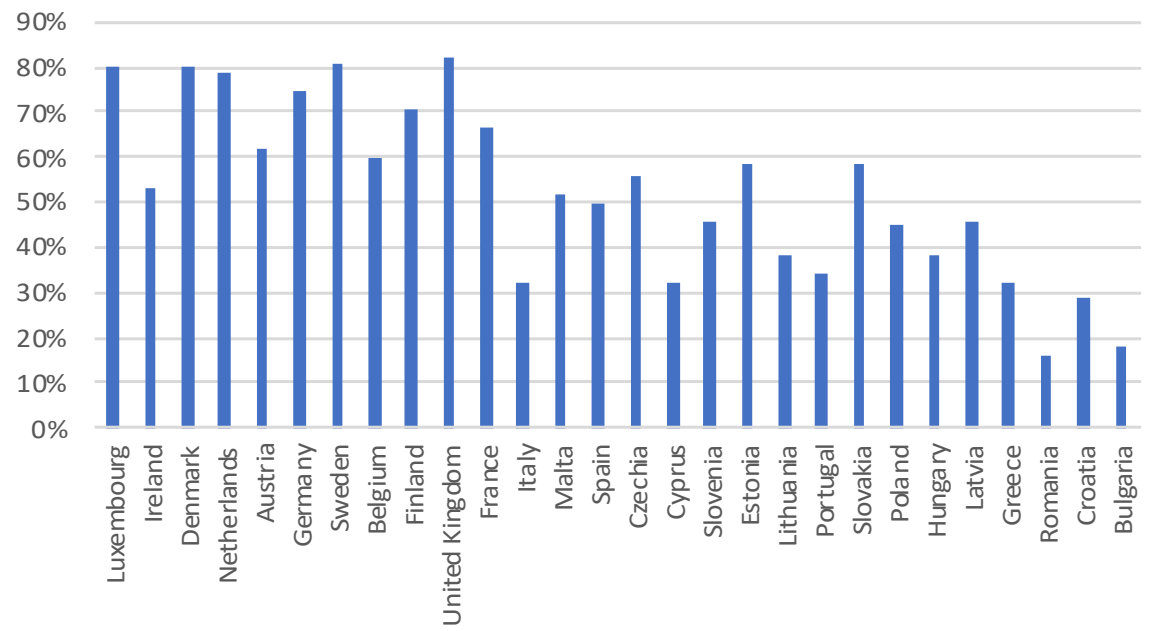

Figure 5. The proportion of individuals who bought online in the last 12 months online (source: Czech Statistical Office)

Individuals from the Czech Republic are buying not only in the Czech Republic but also in the whole EU 28. The most purchases in the Czech Republic were made in 2018 (4 291800 actions), purchases from the EU countries were 874900 and 475200 purchases were realized from countries outside the EU. The trend (focus period was 2012-2018) is increasing in all countries where Czech individuals were buying from.

The most frequent buyers in the EU who purchase from other EU members are Luxembourg, Austria, Malta, Belgium, and Ireland, the less frequent EU countries are Greece, the Czech Republic, Bulgaria, Poland, and Romania. Except for the Czech Republic, these countries purchases are less in general. The main barriers that hindered the purchasing from other EU countries are language and delivery costs. Cross-border online purchases can be an indicator of the smooth functioning of the single market for e-commerce and it extends to which consumers make use of wider choices and lower prices. A large majority of e-shoppers in the 12 months prior to the survey made online purchases from sellers in their own country: 88\%, i.e. down by 1 percentage point from 2013 (Eurostat) (see Figure 5).

The chart presents a comparison of goods purchased in the EU and the Czech Republic (Figure 6 and 7). The proportion of purchased goods is similar, except for the category which groups clothes, shoes, and sporting goods and also the group including meals, chemistry, and cosmetics. The biggest group of purchases in EU countries are clothes, shoes, household equipment, books, newspapers, and magazines. EU defines white goods as white goods and toys, the Czech Republic defines this category the same, excluding toys. This gives us two numbers, if we would like to compare the EU and the Czech Republic we add these two numbers together. By adding these two numbers we obtain a number which can be "compared" with the EU to have an approximate result.

The statistics are from 2018 - individuals from EU and the Czech Republic who purchased in the last 12 months. The figure regarding services compares groups of services that are purchased via the internet in the EU and the Czech Republic. The most purchased services in the EU and the Czech Republic are accommodation, tickets for culture and sports events, and the third being transportation. The data are from 2018 - individuals from EU and the Czech Republic who purchased in the last 12 months (see Figure 8). 


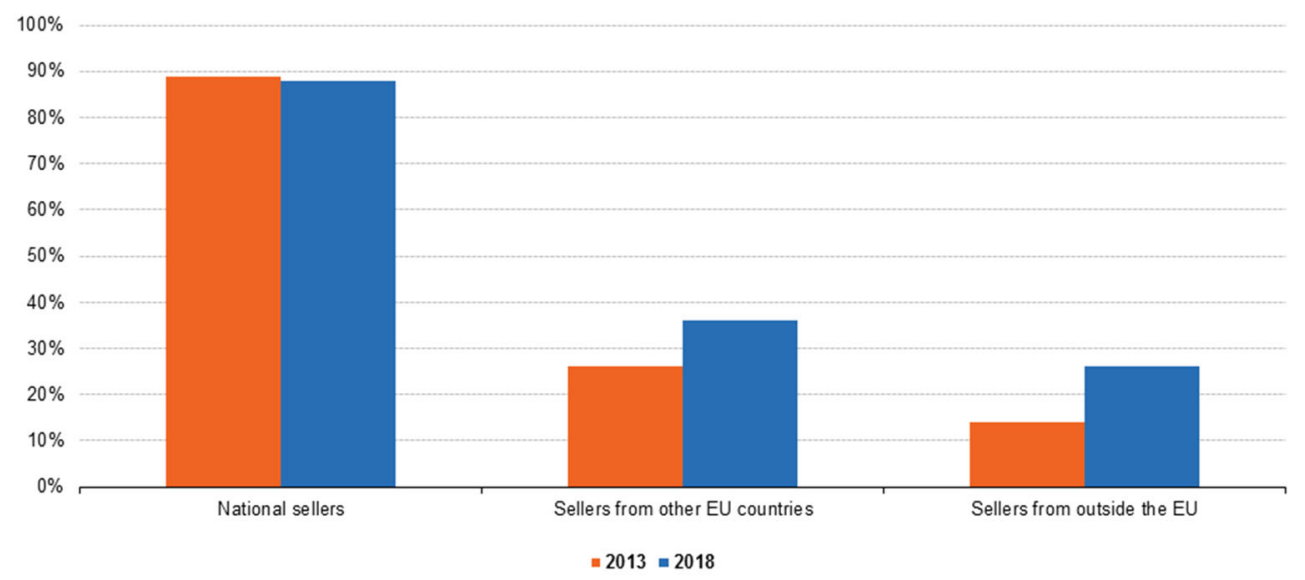

Figure 6. National and Cross-border purchases, EU-28, 2013-2018 (\%of individuals who bought or ordered goods or services over the internet for private use in the previous 12 months (source: Eurostat)

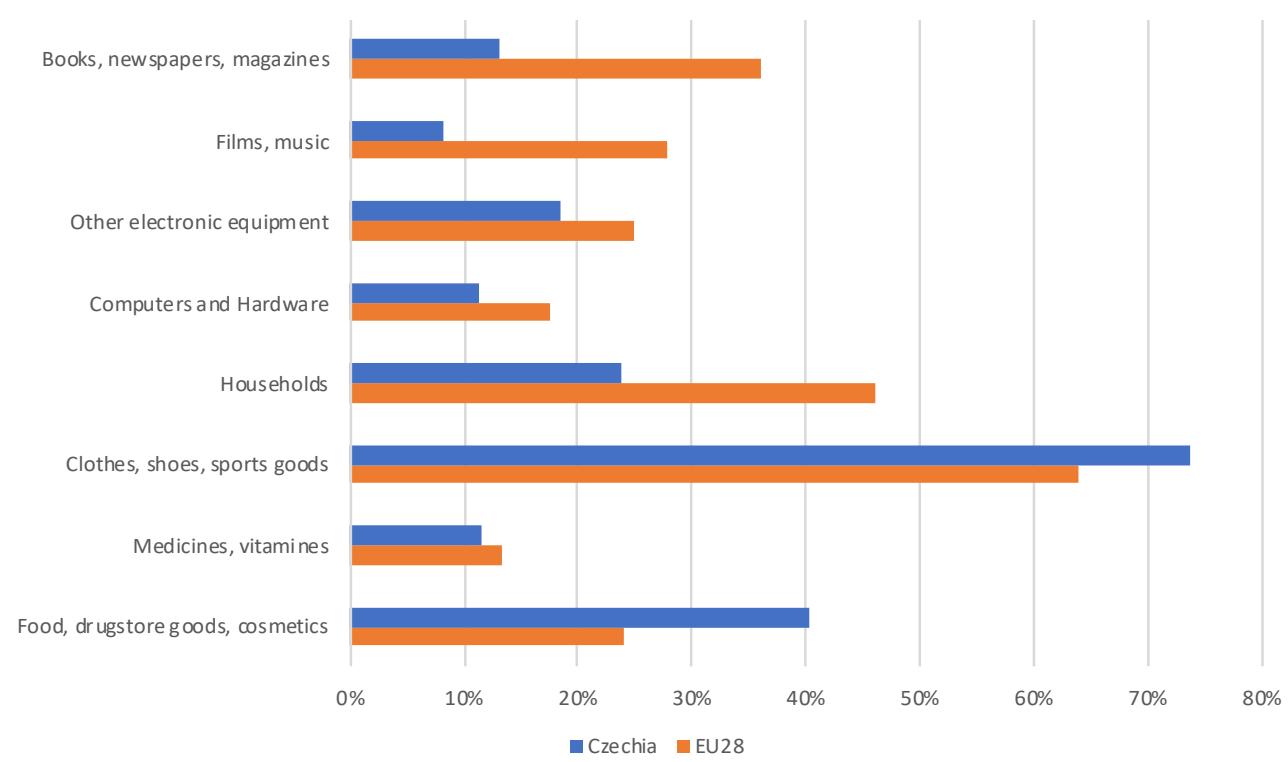

Figure 7. Purchased goods, comparison EU and Czechia (source: Czech Statistical Office)

Tickets for cultural and sport events

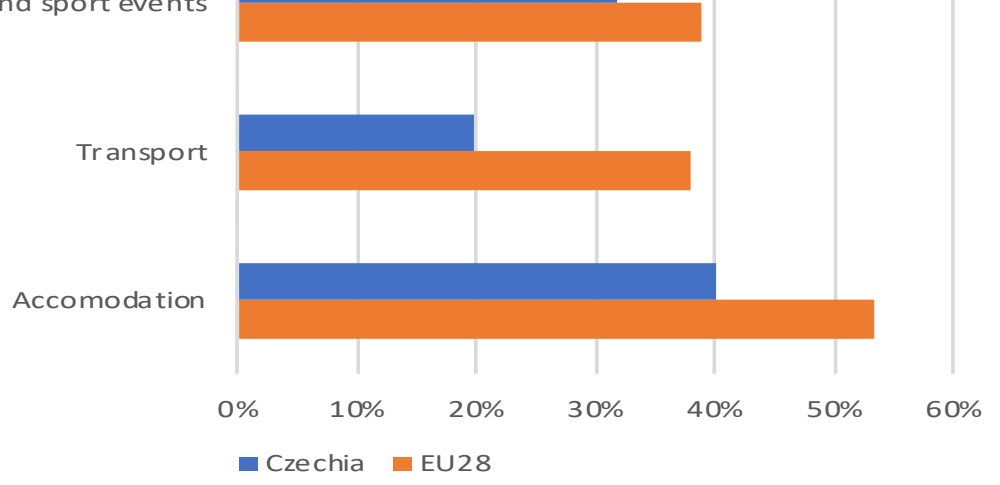

Figure 8. Purchased services, Comparison EU and Czechia (source: Czech Statistical Office) 
One-third of individuals who purchased online spent in the past three months a maximum of 2500 CZK (100 EUR). Half of all buyers spent between 2500 and $10000 \mathrm{CZK}$, and almost one fifth spent more than 10 thousands CZK. Men spent more money than women (but the frequency of finalized purchases by women is increasing). This disproportion is influenced by categories of goods purchased by men and women. Individuals aged 35-44 spent the most, one-fourth of this group spent more than 10 thousand CZK, for three months. The highest spending group are university educated individuals, $30 \%$ of them spent online more than 10 thousand CZK for 3 months (Czech Statistical Office).

Some individuals don't purchase online ever. They mention no possibility of seeing the product, to try, test and or taste it. Therefore $49 \%$ of individuals who don't purchase online prefer shopping in regular stores (data from 2017). Individuals older than 65 years don't purchase regularly because they don't have internet knowledge (77\%). Some of them don't use the internet $(67 \%)$ or they use internet only for basic activity $(10 \%)$. (Czech Statistical Office) Other reasons for not-purchasing online are potential difficulties caused by complaints and misusage of personal data or payments data. Czech commerce discovered that $41 \%$ of individuals who don't purchase online, is because it's not possible to touch the goods, $21 \%$ are afraid of potential problems connected with complaints, $7 \%$ are aware of misusage of banking data and $6 \%$ are aware of misusage of personal data. $21 \%$ don't mention any reason, they don't know why they don't purchase online. (Ceska-e-commerce).

On the other side, $45 \%$ prefer online purchases because of the easy comparison of goods, with $18 \%$ confirming comfortable purchases. $11 \%$ say that they have a large choice of goods, $11 \%$ highlight the saving of money and $9 \%$ prefer online shopping because of lower prices. In general, e-commerce creates $9.1 \%$ of all retail in the Czech Republic, in between years increase is $1 \%$. (Ceska-e-commerce). The trend is connected with technology development, IT connectivity, decreasing prices for data users, decreased prices for IT technologies and smart-phones, and the availability of e-shops solutions for establishing your own e-shop. Commercial statistics expect 42000 in the Czech Republic till the end of the year 2019. Expected revenue is 139 billion CZK which means more than $18.5 \%$ increase between 2018 and 2019.

\section{Conclusions}

This paper has examined the literature review dealing with the digitalization of business processes, cultural backgrounds and consequences on behavioral differences. The purpose of this research is twofold. Firstly, we examine presents a theoretical model for customer purchase behavior and the development of the theory in the $\mathrm{B} 2 \mathrm{C}$ e-commerce context. A difference between traditional and e-commerce customer purchase behavior model was found. The Czech Republic compared to the EU is below average regarding online purchases, despite having more internet users than the average EU citizen. 56\% of Czech individuals between 16 and 74 purchased within the last 12 months (2017). Brands are focused on storytelling. Social media-based brand communities are playing an important role in enhancing the overall trust relationship, value offering, sociality, knowledge and information sharing between customers and firms.

Secondly, the paper is analyzing the main aspects of shopping behavior in selected countries, the research shows the main characteristics of shopping in B2C and provides a better understanding of the impact of digitalization. The data presented by the Czech Statistical Office show the development of the purchases during the period between 2010 and 2018. The data allowed to compare the situation in the Czech Republic and in the EU. The Czech Republic compared with EU is under average in contrast to having more internet users than average in the EU. The most active being British (82\%), Swedish (81\%), Dansk and Luxembourg (80\%), the less active individuals are from Romania $(16 \%)$, Bulgaria (17\%) and Croatia (29\%). The increasing trend of purchasing is significant within students and mothers on maternity leave demographic groups. Both of these groups are not family members who generate the main family income, but we are expecting that these groups have more time to search for the most convenient goods on the internet. On the other side, we cannot forget the increasing trend of the amount of e-shops. Above mentioned analyses are evident to show high potential e-shopping at all. The paper confirmed the fact that the $\mathrm{B} 2 \mathrm{C}$ e-commerce market in the Czech Republic is developed and has potential to grow nationally and internationally. From the above, it follows that it is necessary to further investigate the relationship between customer purchase behavior, e-commerce, and other economic indicators, possibly including other factors.

\section{References}

Alam, S., Ali, M., \& Jani, M. (2011). An empirical study of factors affecting electronic commerce adoption among SMEs in Malaysia. Journal of Business Economics and Management, 12(2), 375-399. https://doi.org/10.3846/16111699.2011.576749

APEK (2018). Association for e-commerce 2019. Retrieved from: https://www.apek.cz

Armstrong, G., \& Kotler, P. (2011). Marketing: An Introduction (Global Edition). Harlow (UK): Pearson Education Limited.

Belch, G. E., \& Belch, M. A. (2004). Advertising and Promotion: An Integrated Marketing Communications Perspective 6th. New York: NY: McGraw-Hill.

Bhatt, G. D., \& Emdad, A. F. (2001). An analysis of the virtual value chain in electronic commerce. Logistics Information Management, 14(1/2), 78-85. https://doi.org/10.1108/09576050110362465 
Borden, N. H. (1965). The concept of the marketing mix. In Schwartz, G. (Ed), Science in marketing (pp. 386-397). New York: John Wiley \& Sons.

Czech e-commerce (2018). E-commerce market. Retrieved from: https://www.ceska-ecommerce.cz

Chaffey, D., \& Ellis-Chadwick, F. (2019). Digital Marketing. Harlow (UK): Pearson Education Limited.

CMI (2017). Content Marketing Institute. Retrieved from CMI website: www.contentmarketinginstitute.com/what-is-content-marketing

Constantinides, E. (2002). The 4S web-marketing mix model. Electronic commerce research and applications, 1(1), 57-76. https://doi.org/10.1016/S1567-4223(02)00006-6

Czech Statistical Office (2018). Use of information and communication technologies in households and between individuals - 2018. Retrieved from: https://www.czso.cz/csu/czso/vyuzivani-informacnich-a-komunikacnich-technologii-v-domacnostech-amezi-jednotlivci

Dhingra, M., \& Dhingra, V. (2013). Determinants of Electronic customer relationship management (e-CRM) for customer satisfaction in the banking sector in India. African Journal of Business Management, 7(10), 762-768.

Eurostat. (2018). E-commerce statistics. Retrieved from: https://ec.europa.eu/eurostat/statistics-explained/index.php/Ecommerce_statistics\#E-sales_remain_stable_over_recent_years

Eurostat. (2018). E-commerce statistics for individuals. Retrieved from: https://ec.europa.eu/eurostat/statisticsexplained/index.php?title=E-commerce_statistics_for_individuals\#E-

shopping:_biggest_increase_among_young_internet_users

Forouzandeh, S., Soltanpanah, H., \& Sheikhahmadi, A. (2014). Content marketing through data mining on the Facebook social network. Webology, 11(1), 1-11.

Huber, F., Herrmann, A., \& Morgan, R. E. (2001). Gaining competitive advantage through customer value-oriented management. Journal of consumer marketing, 18(1), 41-53. https://doi.org/10.1108/07363760110365796

Järvinen, J., \& Taiminen, H. (2016). Harnessing marketing automation for B2B content marketing. Industrial Marketing Management, 54, 164-175. https://doi.org/10.1016/j.indmarman.2015.07.002

Kim, J., \& Choi, H. (2019). Value co-creation through social media: a case study of a start-up company. Journal of Business Economics and Management, 20 (1), 1-19. https://doi.org/10.3846/jbem.2019.6262

Kumar, N., \& Malik, K. (2013). E-CRM golden opportunity for banks. International Journal of Multidisciplinary and Academic Research, 2, 1-10.

Maroofi, F., Darabi, A., \& Torabi, J. (2012). Effects of E-CRM on customer-bank relationship quality and result. International Journal of Academic Research in Accounting, Finance and Management Sciences, 2(3), 164-182.

McCarthy, E. J. (1964). Basic Marketing. New York: R. D. Irwin.

McCarthy, E. J. (1978). Basic marketing: a managerial approach. RD Irwin.

Mercadé-Melé, P., Molinillo, S., Fernández-Morales, A., \& Porcu, L. (2018). CSR activities and consumer loyalty: the effect of the type of publicizing medium. Journal of Business Economics and Management, 19(3), 431-455. https://doi.org/10.3846/jbem.2018.5203

Mindak, W. A., \& Fine, S. (1981). A fifth 'P': public relations. In J. H. Donnely, \& W. R. George (Eds), Marketing of Services, American Marketing Association (pp. 71-73), Chicago: IL.

Momani, A. M., \& Jamous, M. (2017). The evolution of technology acceptance theories. International Journal of Contemporary Computer Research (IJCCR), 1(1), 51-58.

Montazeribarforoushi, S., Keshavarzsaleh, A., \& Ramsøy, T. Z. (2017). On the hierarchy of choice: An applied neuroscience perspective on the AIDA model. Cogent Psychology, 4(1), 1363343. https://doi.org/10.1080/23311908.2017.1363343

Mosteller, J., Donthu, N., \& Eroglu, S. (2014). The fluent online shopping experience. Journal of Business Research, 67(11), 24862493. https://doi.org/10.1016/j.jbusres.2014.03.009

Potgieter, L. M., \& Naidoo, R. (2017). Factors explaining user loyalty in a social media-based brand community. South African Journal of Information Management, 19(1), 1-9. https://doi.org/10.4102/sajim.v19i1.744

Pulizzi, J. (2012). The Rise of Storytelling as new Marketing. Public Research Quarterly, 28, 116-123. https://doi.org/10.1007/s12109-012-9264-5

Reichheld, F. F., Robert Jr, G., \& Hopton, C. (2000). The loyalty effect--the relationship between loyalty and profits. European Business Journal, 12(3), 134-134.

Solomon, M. R. (2010). Consumer behavior: A European perspective. Harlow (UK): Pearson Education Limited.

Van Waterschoot, W., \& Van den Bulte, C. (1992). The 4P classification of the marketing mix revisited. Journal of marketing, 56(4), 83-93. https://doi.org/10.1177/002224299205600407 